\title{
Pyrrolidine Derivatives as New Inhibitors of $\alpha$-Mannosidases and Growth Inhibitors of Human Cancer Cells
}

\author{
Hélène Fiaux§a, Catherine Schütz ${ }^{\mathrm{a}}$, Pierre Vogela ${ }^{\mathrm{a}}$, Lucienne Juillerat-Jeanneret ${ }^{\star b}$, \\ and Sandrine Gerber-Lemaire*a \\ §METTLER TOLEDO Award Winner (Oral Presentation)
}

\begin{abstract}
New pyrrolidine-3,4-diol derivatives were prepared from D-(-)- and L-(+)-phenylglycinol and tested for their ability to inhibit 25 commercial glycosidases. The influence of the substitution of the lateral side chain and of the pyrrolidine ring on the enzyme inhibition was evaluated. $(2 R, 3 R, 4 S)-2-(\{[(1 R)-2-$ Hydroxy-1-phenylethyl]amino $\}$ methyl)pyrrolidine-3,4-diol was a potent and selective inhibitor of $\alpha$-mannosidase from jack bean. This compound was derivatized into lipophilic esters in order to allow its internalization by human cancer cells. In particular, the 4bromobenzoate derivative demonstrated promising inhibition of glioblastoma and melanoma cells whereas it was less effective on healthy human fibroblasts.
\end{abstract}

Keywords: Glioblastoma $\cdot$ Growth inhibition $\cdot \alpha$-Mannosidase inhibitor $\cdot$ Melanoma $\cdot$ Pyrrolidine derivatives

\section{Introduction}

Very few therapeutic options exist for the treatment of human glioblastoma and metastatic melanoma, in part due to their resistance to chemotherapeutic agents [1]. Therefore new drugs have to be developed that are able to overcome drug resistance, and such novel approaches may be represented by agents targeting the glycosylation pathways of cancer cells. Aberrant glycosylation of glycoproteins and glycolipids was reported to be one of the molecular changes that accompany malignant transformations [2]. As both catabolic and processing glycosidases are involved in the transforma-

\footnotetext{
${ }^{*}$ Correspondence: Dr. HDR S. Gerber-Lemaire ${ }^{a}$ Tel.: + 41216939372

Fax: + 41216939355

E-Mail: Sandrine.Gerber@epfl.ch

Dr. Dr. L. Juillerat ${ }^{\mathrm{b}}, \mathrm{PhD}, \mathrm{PD}, \mathrm{MER}$

Tel.: +4121314 7173

Fax: +4121314 7115

E-Mail: lucienne.juillerat@chuv.hospvd.ch

aLaboratory of Organic Chemistry and Asymmetric

Synthesis

Ecole Polytechnique Fédérale de Lausanne

Batochime

$\mathrm{CH}-1015$ Lausanne

bUniversity Institute of Pathology

CHUV

Bugnon 25

$\mathrm{CH}-1011$ Lausanne
}

tion of normal cells to cancer cells and in tumor cell invasion and migration [3], it has been proposed that the specific inhibition of $\alpha$-mannosidases involved in the addition of N-linked carbohydrates to glycoproteins may provide a new anti-cancer strategy [46] able to overcome resistance to conventional chemotherapeutic agents. Clinical trials have demonstrated that swainsonine, a natural inhibitor of Golgi $\alpha$-mannosidase II, which contains a 4-amino-4-deoxymannofuranoside moiety [7], decreases the growth of solid tumors and hematological malignancies [8]. In particular, Kino et al. were the first to report that the subcutaneous administration of swainsonine completely inhibited the growth and the formation of lung metastases of sarcoma [9]. Nevertheless, the toxicity observed for this alkaloid as well as the undesired co-inhibition of lysosomal mannosidases, which may induce lysosomal storage diseases, resulted in the search for new and more selective $\alpha$-mannosidases inhibitors. Some analogues of swainsonine such as 2 (Fig. 1) as well as simpler derivatives, have shown interesting inhibitory properties [10-12]. We recently developed a combinatorial methodology for the rapid discovery of glycosidase inhibitors [13] which led to the synthesis of a new family of 3,4-dihydroxy-pyrrolidin-2-yl derivatives (3-5) as selective and competitive inhibitors of $\alpha$-mannosidase from jack bean, a model for mammalian $\alpha$-mannosidases [14-16]. Here we report the synthesis of new derivatives of diamine $\mathbf{3}$ and their evaluation as glycosidase inhibitors and as growth inhibitors of human glioblastoma and melanoma cells.

\section{Results and Discussion}

\section{Synthesis of New Pyrrolidine Derivatives}

The fully protected carbaldehyde 6 [17] was submitted to a reductive amination procedure in the presence of phenylglycinol or phenylalaninol derivatives and sodium triacetoxyborohydride for in situ reduction of the intermediate imines (Scheme 1) Acidic treatment of the resulting diamines afforded derivatives 8a-8e with 40-74\% yield. In order to introduce a methyl substituent at the $\mathrm{C}(5)$ position of the pyrroldine ring the protected lactam 9 [18] was treated with methylmagnesium bromide to afford methyl ketone $\mathbf{1 0}$ in $67 \%$ yield. Reduction of the carbonyl group followed by mesylation of the resulting alcohol and cyclization under basic conditions $(t \mathrm{BuOK}, 0$ ${ }^{\circ} \mathrm{C}$ ) afforded functionalized pyrrolidines $\mathbf{1 1}$ and 12 in $40-35 \%$ yield, respectively. The two isomers were easily separated by chromatography and transformed into the corresponding carbaldehydes through Birch reduction of the trityl protecting group and oxidation of the resulting alcohol under Swern conditions. Reductive amination in the presence of phenylglycinol followed 


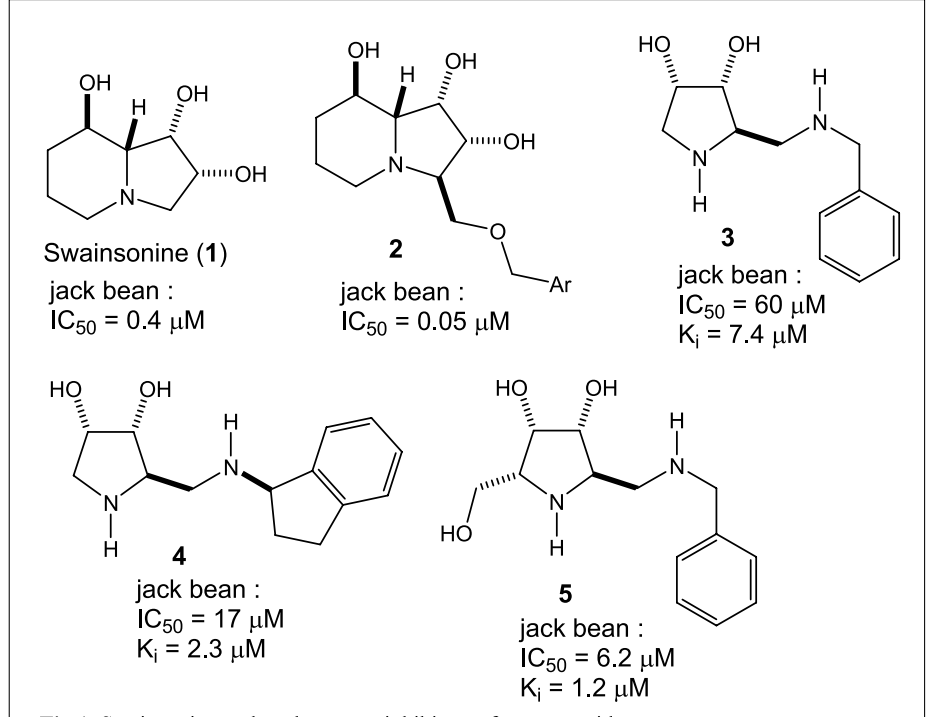

Fig. 1. Swainsonine and analogues as inhibitors of $\alpha$-mannosidases

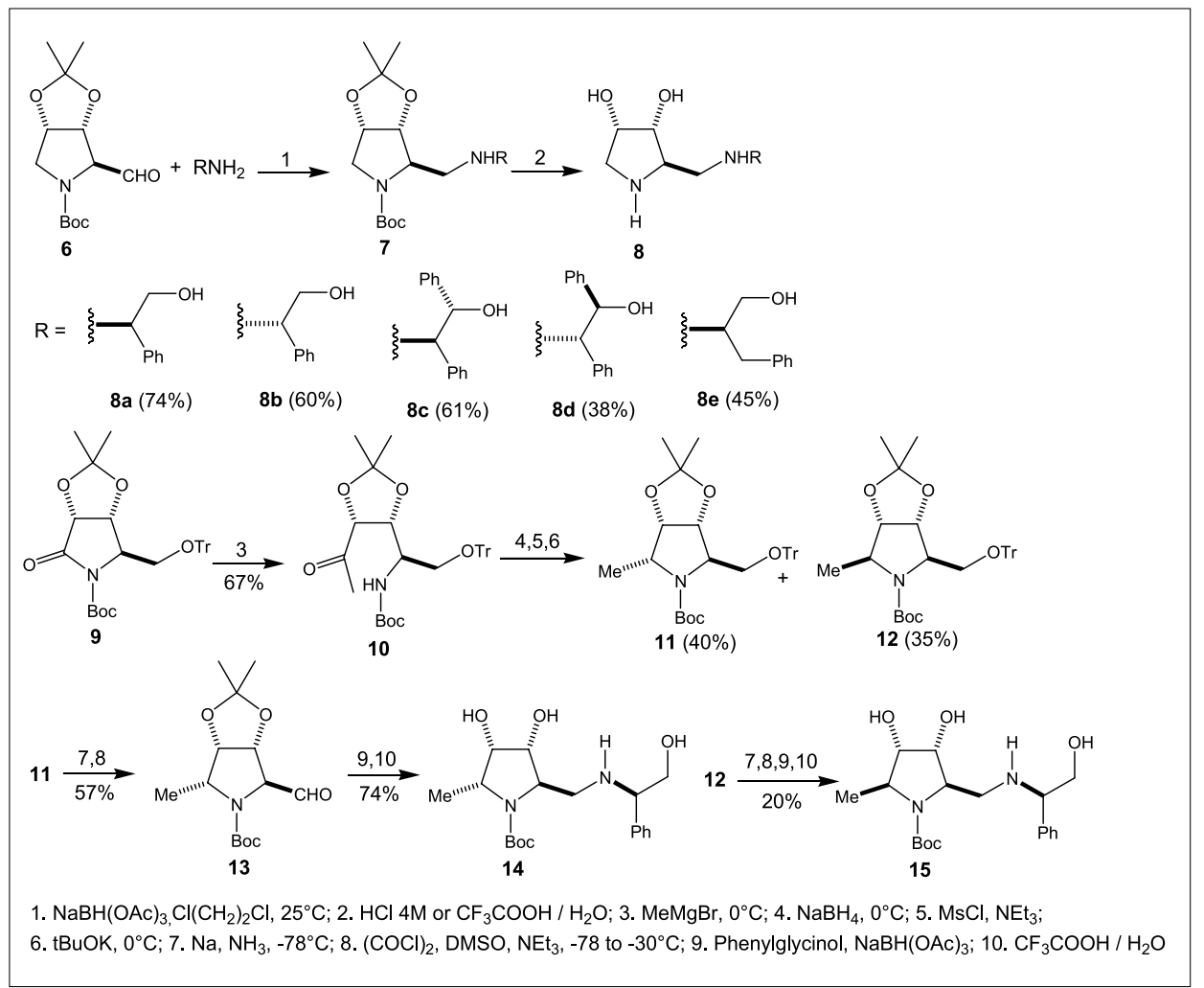

Scheme 1. Synthesis of pyrrolidine derivatives

by acidic removal of the protecting groups provided diamines 14 and 15 with a methyl substituent at the $\mathrm{C}(5)$ position of the pyrrolidine ring.

Introduction of ester moieties on the primary hydroxyl group of derivative 8a was envisaged in order to increase its lipophilicity and thus improve cell membrane penetration (Scheme 2). d-(-)- $\alpha$-Phenylglycinol was protected as a tert-butyl carbamate (16), allowing acylation of the primary alcohol with aliphatic and substituted aromatic acyl chlorides. After acidic treatment, the resulting amines were also engaged in a reductive amination procedure with pyrrolidine carbaldehyde 6 to provide compounds 18-27 after quantitative cleavage of the Boc and acetonide protecting groups.

\section{Inhibition of Purified Glycosidases}

The inhibitory ability of derivatives 8a-8e, 14 and 15 toward 25 commercially available glycosidases was determined. The data are summarized in Table 1 . None of these compounds inhibited $\alpha$-l-fucosidases (from bovine epididymis or human placenta), $\alpha$ - and $\beta$-galactosidases (from coffee beans, aspergillus niger, aspergil- lus orizae, escherichia coli or jack bean), $\alpha$ - and $\beta$-glucosidases (from yeast, rice, aspergillus niger, rhizopus mold, almond or caldocellum saccharol.), $\beta$-mannosidases (from helix pomatia), $\beta$-xylosidase (from aspergillus niger), $\alpha$-N-acetylgalactosaminidase and $\beta$-N-acetylglucosaminidase (from chicken liver) (data not shown). However, $\alpha$-mannosidases from jack bean and almond were inhibited by these derivatives with high selectivity. In particular the d-(-)$\alpha$-phenylglycinol substituted derivative 8a was a potent $\left(\mathrm{K}_{\mathrm{i}}=135 \mathrm{nM}, \mathrm{IC}_{50}=700 \mathrm{nM}\right)$ competitive (as determined on a Lineweaver and Burk plot) inhibitor of jack bean $\alpha$ mannosidase, a reliable model enzyme for mammalian Golgi $\alpha$-mannosidases II [19]. but was less potent for almond $\alpha$-mannosidase. Introduction of an hydroxymethyl group on the lateral side chain of the pyrrolidine ring led to a considerable increase of the inhibitory potential in comparison with the non-substituted derivative $\mathbf{3}$ ( $\mathrm{IC}_{50}$ $=60 \mu \mathrm{M}$ for $\mathbf{3} v s \mathrm{IC}_{50}=0.7 \mu \mathrm{M}$ for $\mathbf{8 a}$, factor of increase $=85$ ). Its diastereoisomer 8b was much less active $\left(\mathrm{IC}_{50}=100 \mu \mathrm{M}\right)$, demonstrating the influence of the stereochemistry of the lateral side chain of the pyrrolidine for optimal recognition by the enzyme. The introduction of an additional aromatic group (8c, $\mathbf{8 d}$ ) led to a significant decrease of the inhibitory activity toward both mannosidases. The steric hindrance of these derivatives may prevent their entrance into the active site of the enzyme. Similarly, the elongation of the aromatic side chain (8e) resulted in a dramatic loss of $\alpha$-mannosidase inhibition. The introduction of a methyl substituent at the $\mathrm{C}(5)$ position of the pyrrolidine (14), on the $\alpha$-face, also decreased the inhibitory activity toward $\alpha$ mannosidase from jack bean $\left(\mathrm{IC}_{50}=134\right.$ $\mu \mathrm{M} v s \mathrm{IC}_{50}=0.7 \mu \mathrm{M}$ for 8a). The epimer derivative 15 was inactive on glycosidases, pointing out the influence of the configuration of the pyrrolidine substituents on the inhibitory properties of these compounds.

The free hydroxyl group on the lateral side chain seemed to be also determining for inhibition since the ester derivatives 1827 were less active than the parent unprotected compound $8 \mathbf{a}\left(\mathrm{IC}_{50}=55\right.$ to $600 \mu \mathrm{M}$ vs $\mathrm{IC}_{50}=0.7 \mu \mathrm{M}$ for $\mathbf{8 a}$, data not shown). This can be explained by an increase of the steric hindrance as well as the loss of a potential hydrogen bonding with the active site of the enzyme.

\section{Evaluation of Functionalized Pyrro- lidines in Human Glioblastoma and Melanoma Cells or Fibroblasts}

First, the effects of derivatives $\mathbf{8 a}-\mathbf{8 e}, \mathbf{1 4}$ and 15 were determined in human LN18 and LNZ308 glioblastoma cells using the MTT ((3,4,5-dimethylthiazol-yl)-2,5-diphenyl tetrazolium) assay, which determines the 


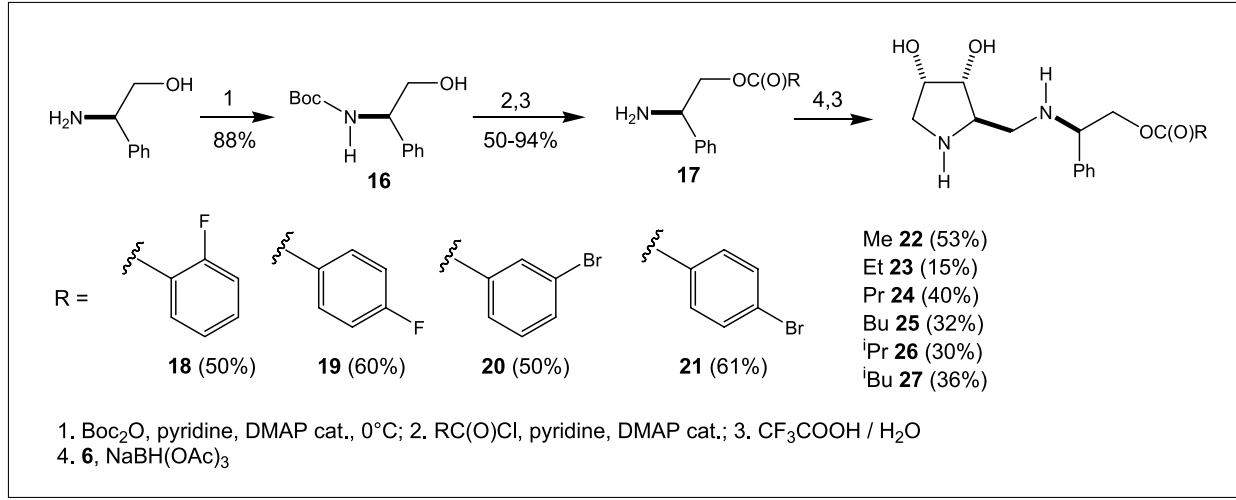

Scheme 2. Pyrrolidine derivatives substituted with phenylglycinol esters

Table 1. Inhibitory activities of pyrrolidine derivatives toward $\alpha$-mannosidases from jack bean or almond. Percent inhibition at $1 \mathrm{mM}$ and optimal $\mathrm{pH}$. (C): competitive inhibition.

\begin{tabular}{|c|c|c|}
\hline Inhibitor & $\begin{array}{l}\alpha-\text { mannosidase } \\
\text { (jack bean) }\end{array}$ & $\begin{array}{l}\alpha-\text { mannosidase } \\
\text { (almond) }\end{array}$ \\
\hline 3 & $\begin{array}{c}92 \%(\mathrm{C}) \\
\mathrm{IC}_{50}=60 \mu \mathrm{M}, \mathrm{K}_{\mathrm{i}}=7.4 \mu \mathrm{M}\end{array}$ & $\begin{array}{c}69 \%(\mathrm{C}) \\
\mathrm{IC}_{50}=230 \mu \mathrm{M}, \mathrm{K}_{\mathrm{i}}=71 \mu \mathrm{M}\end{array}$ \\
\hline $8 a$ & $\begin{array}{c}100 \%(C) \\
I_{50}=700 n M, K_{i}=135 n M\end{array}$ & $\begin{array}{c}93 \%(\mathrm{C}) \\
\mathrm{IC}_{50}=46 \mu \mathrm{M}, \mathrm{K}_{\mathrm{i}}=9.5 \mu \mathrm{M}\end{array}$ \\
\hline $8 b$ & $\begin{array}{c}92 \% \\
\mathrm{IC}_{50}=100 \mu \mathrm{M}\end{array}$ & $55 \%$ \\
\hline $8 c$ & $\begin{array}{c}88 \% \\
\mathrm{IC}_{50}=110 \mu \mathrm{M}\end{array}$ & $55 \%$ \\
\hline $8 d$ & $\begin{array}{c}84 \% \\
\mathrm{IC}_{50}=128 \mu \mathrm{M}\end{array}$ & $50 \%$ \\
\hline $8 e$ & $\begin{array}{l}50 \% \\
\text { nd }\end{array}$ & $\begin{array}{l}30 \% \\
\text { nd }\end{array}$ \\
\hline 14 & $\begin{array}{c}82 \% \\
I_{50}=134 \mu \mathrm{M}\end{array}$ & $\begin{array}{l}\text { nd } \\
\text { nd }\end{array}$ \\
\hline 15 & no inhibition & nd \\
\hline
\end{tabular}

number of metabolically active cells. These derivatives did not display any significant activity (results not shown). Swainsonine, an $\alpha$-mannosidase inhibitor with promising anti-tumor properties [4][7-9] only inhibited by $20 \%$ glioblastoma cell growth at $250 \mu \mathrm{M}$ and was not active at lower concentration. Compound $\mathbf{8 a}$, the most active inhibitor for plant $\alpha$-mannosidases was not active on human glioblastoma cells. These discrepant effects could result from poor cell membrane permeability and a low uptake of these compounds by glioblastoma cells. Introduction of lipophilic aromatic ester groups on the lateral side chain of 8a led to an increase of the growth inhibition of glioblastoma cells (Table 2) [20]. In particular, the 4-bromobenzoyl ester 21 was the most efficient derivative with complete inhibition of glioblastoma cell growth at a concentration of $300 \mu \mathrm{M}$ (LN18 and LNZ318 cell lines). However, the introduction of aliphatic ester groups did not provide a significant increase of the anti-proliferative activity in comparison with compound 8a. 4-Bromobenzoic acid or ethyl 4-bromobenzoate, which may result from the hydrolysis of $\mathbf{2 1}$ by cell esterases, were had no effect on glioblastoma and melanoma cell growth (results not shown) excluding an effect of the aromatic substituent. A dose-response evaluation $(300-100 \mu \mathrm{M})$ of the anti-proliferative effects of 21 (Fig. 2A) in both glioblastoma cells demonstrated the increased efficacy of 21 compared to swainsonine (Fig. 2B). The $\mathrm{IC}_{50}$ for 21 was determined to be 125 $\mu \mathrm{M}$ in LN18 and LNZ308 cells. We then evaluated whether $\mathbf{2 1}$ has the potential to diminish cell growth by inhibiting the synthesis of DNA, and/or of proteins. The evaluation of the incorporation of $\left[{ }^{3} \mathrm{H}\right]-$ thymidine and $\left[{ }^{3} \mathrm{H}\right]$-Leu following $6 \mathrm{~h}$ exposure of the cells to these molecules demonstrated that $\mathbf{2 1}$ inhibited thymidine incorporation, therefore DNA synthesis (Fig. 3A) at slightly lower concentration and higher extent than leucine incorporation, therefore protein synthesis (Fig 3B). These results suggest that this molecule acts initially by inhibiting DNA synthesis (93\% inhibition at $300 \mu \mathrm{M}$ in LN18), then the rate of protein synthesis will decrease (82\% at $300 \mu \mathrm{M}$ in $\mathrm{LN} 18)$, resulting in diminished cell survival. Furthermore, we determined whether this compound was also able to inhibit DNA and protein synthesis and survival in human cancer cells originating from a tumor different of glioblastoma, the melanoma. Exposure of human Me237 and Me275 melanoma cells for $6 \mathrm{~h}$ to 21 resulted in blockage of DNA synthesis and protein synthesis, and after $24 \mathrm{~h}$, the number of metabolically active melanoma cells decreased (Fig. 4), as determined using the MTT assay.

Finally we evaluated the sensitivity of human fibroblasts, as models for non-tumor cells to 21 (Fig. 5). Fibroblasts were less sensitive to this compound than glioblastoma and melanoma cells for survival after $24 \mathrm{~h}$ exposure suggesting some cell selectivity of $\mathbf{2 1}$ between tumor and nontumor cells.

\section{Conclusion}

In conclusion, a series of functionalized pyrrolidines have been prepared and evaluated as inhibitors of mannosidases. The phenylglycinol derivative 8a was shown to be a potent, selective and competitive inhibitor of $\alpha$-mannosidase from jack bean ( $\mathrm{K}$ $=135 \mathrm{nM}$ ). However, it did not inhibit the growth of human tumor cells. We postulated that its hydrophilic character prevented its internalization by cells. In support of this hypothesis, the more lipophilic derivative 21 inhibited the growth of human glioblastoma and melanoma cells, more than the growth of human fibroblasts, and more efficiently than swainsonine, a potential anti-tumor agent. The presence of lipophilic substituents increased efficacy making these derivatives able to inhibit DNA and protein synthesis and tumor cell survival. The 4-bromobenzoyl group was the most efficient substituent to promote tumor cell growth inhibition, which we postulated to be due to improved cell uptake of compound $\mathbf{8 a}$ by human cancer cells. Thus the exposure of tumor cells to ester derivatives of prodrug analogs of $\mathbf{2 1}$ would result in two advantages: the hydrolysis of the ester would release mol- 
Table 2. Growth inhibition of glioblastoma cells by functionalized pyrrolidines. Cells were exposed for $24 \mathrm{~h}$ to $0,100,200$ or $300 \mu \mathrm{M}$ of the various synthetic derivatives, then the MTT assay was performed for the last two hours of incubation. The \% of residual mitochondrial activity was calculated as the ratio of treated to control cells.

\begin{tabular}{|c|c|c|c|c|}
\hline & & $100 \mu \mathrm{M}$ & $200 \mu \mathrm{M}$ & $300 \mu \mathrm{M}$ \\
\hline Swainsonine (1) & $\begin{array}{c}\text { LN } 18 \\
\text { LNZ } 308\end{array}$ & $\begin{array}{c}7 \\
25\end{array}$ & $\begin{array}{l}18 \\
24\end{array}$ & $\begin{array}{l}13 \\
16\end{array}$ \\
\hline $8 a$ & $\begin{array}{c}\text { LN } 18 \\
\text { LNZ } 308\end{array}$ & $\begin{array}{c}13 \\
0\end{array}$ & $\begin{array}{c}19 \\
8\end{array}$ & $\begin{array}{l}22 \\
26\end{array}$ \\
\hline 18 & $\begin{array}{c}\text { LN } 18 \\
\text { LNZ } 308\end{array}$ & $\begin{array}{l}0 \\
0\end{array}$ & $\begin{array}{l}17 \\
18\end{array}$ & $\begin{array}{l}26 \\
23\end{array}$ \\
\hline 19 & $\begin{array}{c}\text { LN } 18 \\
\text { LNZ } 308\end{array}$ & $\begin{array}{l}9 \\
4\end{array}$ & $\begin{array}{l}22 \\
16\end{array}$ & $\begin{array}{l}20 \\
21\end{array}$ \\
\hline 20 & $\begin{array}{c}\text { LN } 18 \\
\text { LNZ } 308\end{array}$ & $\begin{array}{l}8 \\
5\end{array}$ & $\begin{array}{c}10 \\
5\end{array}$ & $\begin{array}{l}16 \\
17\end{array}$ \\
\hline 21 & $\begin{array}{c}\text { LN } 18 \\
\text { LNZ } 308\end{array}$ & $\begin{array}{c}4 \\
18\end{array}$ & $\begin{array}{l}54 \\
83\end{array}$ & $\begin{array}{l}100 \\
100\end{array}$ \\
\hline 22 & $\begin{array}{c}\text { LN } 18 \\
\text { LNZ } 308\end{array}$ & $\begin{array}{l}5 \\
3\end{array}$ & $\begin{array}{l}0 \\
9\end{array}$ & $\begin{array}{l}11 \\
17\end{array}$ \\
\hline 23 & $\begin{array}{c}\text { LN } 18 \\
\text { LNZ } 308\end{array}$ & $\begin{array}{l}21 \\
17\end{array}$ & $\begin{array}{c}7 \\
11\end{array}$ & $\begin{array}{l}22 \\
20\end{array}$ \\
\hline 24 & $\begin{array}{c}\text { LN } 18 \\
\text { LNZ } 308\end{array}$ & $\begin{array}{c}6 \\
16\end{array}$ & $\begin{array}{l}38 \\
17\end{array}$ & $\begin{array}{l}38 \\
25\end{array}$ \\
\hline 25 & $\begin{array}{c}\text { LN } 18 \\
\text { LNZ } 308\end{array}$ & $\begin{array}{c}6 \\
11\end{array}$ & $\begin{array}{c}9 \\
15\end{array}$ & $\begin{array}{c}16 \\
7\end{array}$ \\
\hline 26 & $\begin{array}{c}\text { LN } 18 \\
\text { LNZ } 308\end{array}$ & $\begin{array}{c}6 \\
12\end{array}$ & $\begin{array}{l}7 \\
6\end{array}$ & $\begin{array}{l}14 \\
20\end{array}$ \\
\hline 27 & $\begin{array}{c}\text { LN } 18 \\
\text { LNZ } 308\end{array}$ & $\begin{array}{l}4 \\
3\end{array}$ & $\begin{array}{l}0 \\
0\end{array}$ & $\begin{array}{l}20 \\
22\end{array}$ \\
\hline
\end{tabular}

ecules more active on mannosidases than the prodrugs, and the hydrophilic character of the active molecules following its intracellular hydrolysis by esterases would prevent its passive diffusion out of the cells. Such a strategy already proved to be efficient for ester derivatives of aminolevulinic acid in the context of photodynamic therapy protocols [21].

\section{Acknowledgements}

We would like to thank Mrs A.C. Diserens, Neurosurgery Division, CHUV, Lausanne, for providing the glioblastoma cell lines, and Dr D. Rimoldi, from the Ludwig Institute, Lausanne, for the gift of the human melanoma cells. This work was supported by grants of the Swiss League and Research against Cancer (grants KFS 1070-09-2000 and KLS-0130802-2003), the Swiss National Foundation for Scientific Research (grants 3152-059219.99, 3152A0-105705, 2100-063567.00/1, 200020100028/1), the Swiss Society for Multiple Sclerosis and the Novartis Foundation for Scientific Research.

Received: February 19, 2006

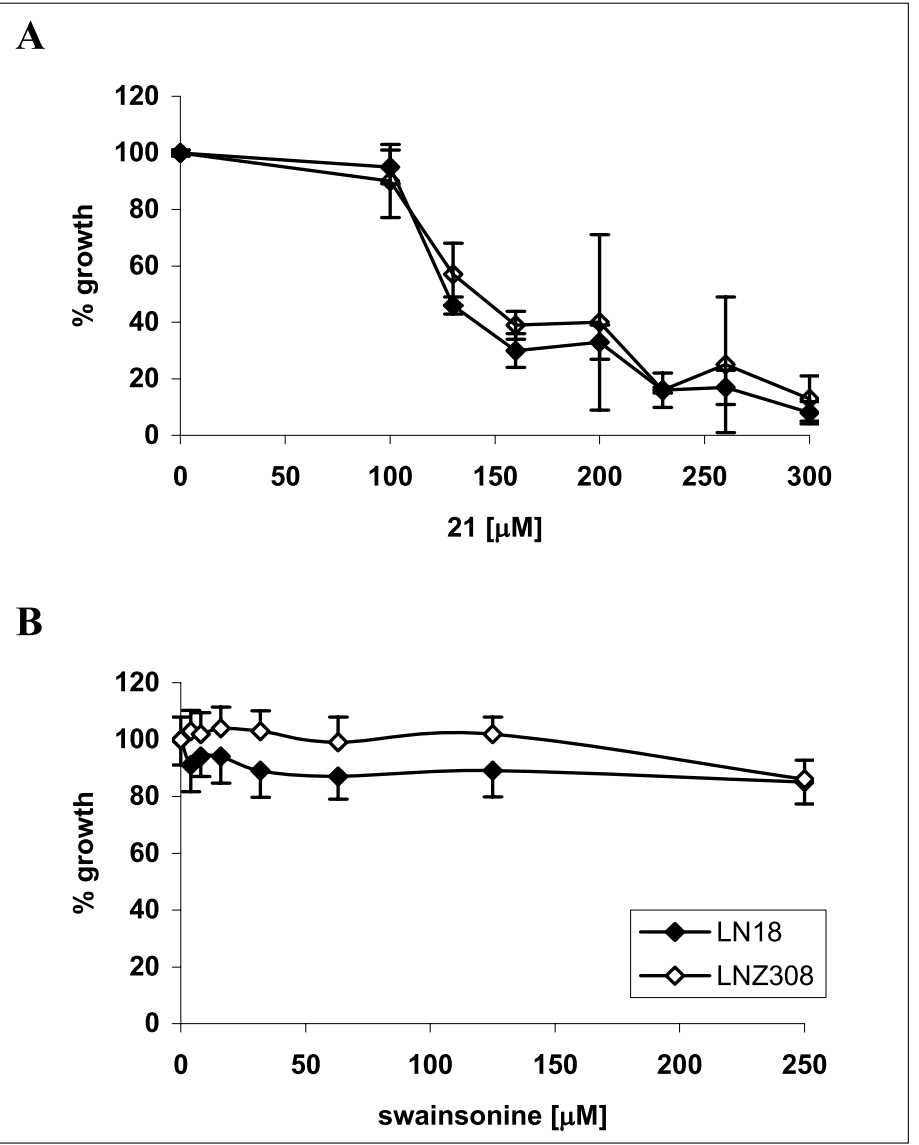

Fig. 2. Growth inhibition of human glioblastoma cells by 21 and swainsonine. Cells were exposed for $24 \mathrm{~h}$ to increasing concentration of either 21 (A) or swainsonine (B), then the MTT assay was performed for the last two hours and the percent of growth was calculated as the ratio of the MTT reduction of treated to untreated cells. Results are shown as means \pm sd of triplicate wells of one representative experiment out of three.
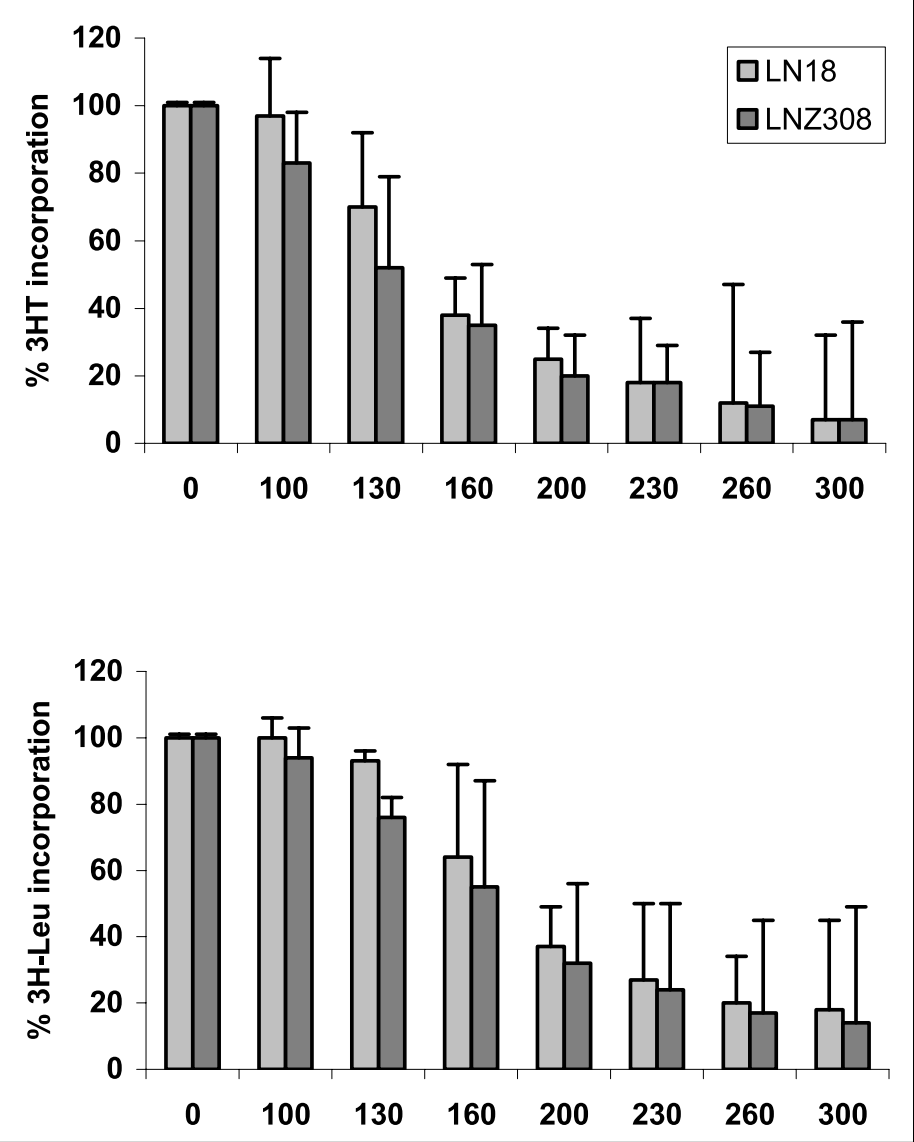

Fig. 3. Inhibition of DNA and protein synthesis by 21 in human glioblastoma cells. Cells were exposed for $6 \mathrm{~h}$ to increasing concentrations of 21. The incorporation of either $(\mathbf{A})$ radioactive thymidine $\left[{ }^{3} \mathrm{HT}\right]$ or $(\mathbf{B})$ radioactive leucine $\left[{ }^{3} \mathrm{H}\right]$ Leu was performed for the last two hours. Light grey bars: LN18, dark grey bars: LNZ308. Results are shown as means \pm sd of triplicate wells of one representative experiment out of three. 


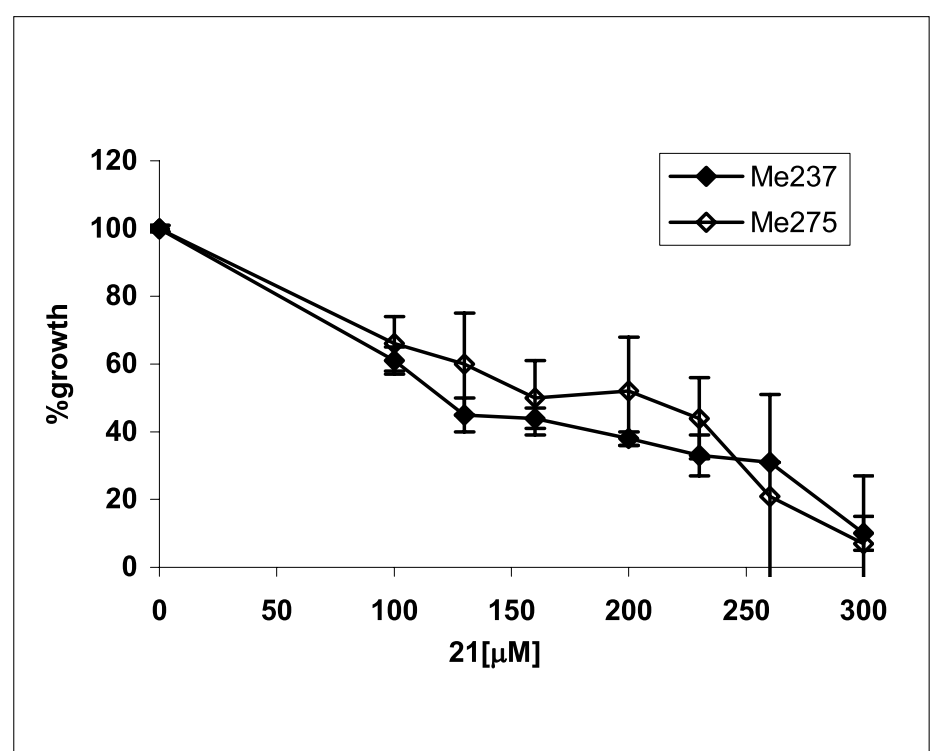

Fig. 4. Growth inhibition of human melanoma cells by 21. Cells were exposed for $24 \mathrm{~h}$ to increasing concentration of $\mathbf{2 1}$, then the MTT assay was performed for the last two hours and the percent of growth was calculated as the ratio of the MTT reduction of treated to untreated cells. Results are shown as means \pm sd of triplicate wells of one representative experiment out of three.

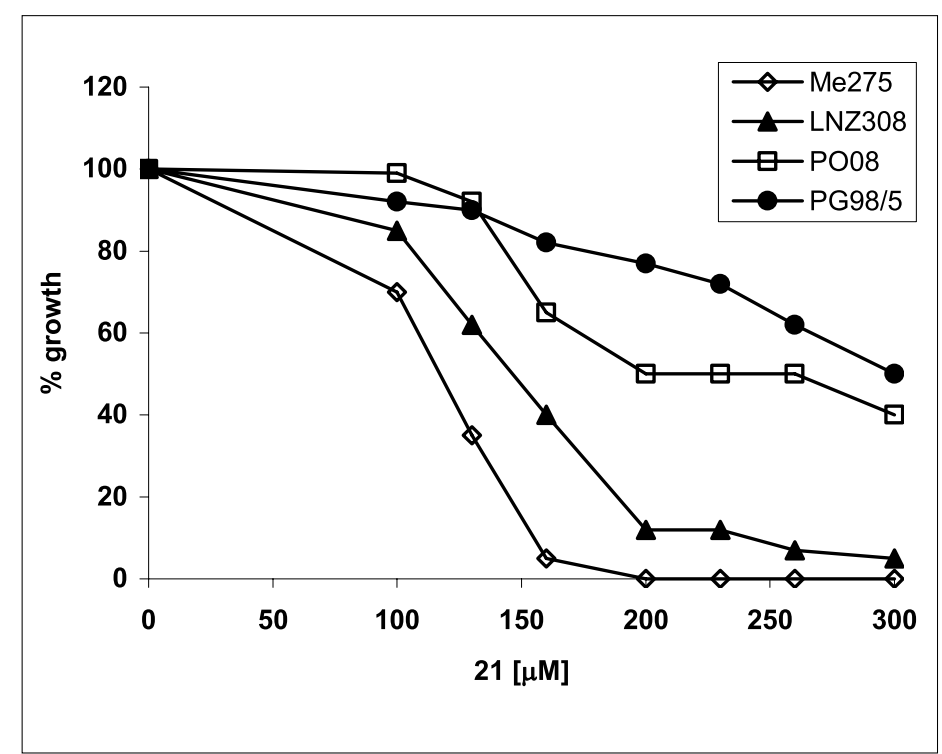

Fig. 5. Comparison of the growth inhibition induced by 21 in human primary fibroblasts and human tumor cells. Human fibroblasts (PG98/5 and PO08) or tumor cells (LNZ308 glioblastoma and Me237 melanoma) cells were exposed to increasing concentration of $\mathbf{2 1}$ for $24 \mathrm{~h}$, then the MTT assay was performed for the last two hours and the percent of growth was calculated as the ratio of the MTT reduction of treated to untreated cells. Results are shown as means \pm sd of triplicate wells of one representative experiment out of three.
[1] J.G. Donnelly, Therap. Drug Monitoring 2004, 26, 231.

[2] S. Hakomori, Cancer Res. 1985, 45, 2405.

[3] J.W. Dennis, M. Granovsky, C.E. Warren, Biochim. Biophys. Acta 1999, 1473, 21-34.

[4] K. Olden, P. Breton, K. Grzegorzewski, Y. Yasuda, B.L. Gause, O.A. Oredipe, S.A. Newton, S.L. White, Pharmacol.Ther. 1991, 50, 285.

[5] J.M. van den Elsen, D.A. Kuntz, D.R. Rose, EMBO J. 2001, 20, 3008.

[6] N. Asano, Glycobiology 2003, 13, 93R.

[7] S.M. Colegate, P.R. Dorling, C.R. Huxtable, Austr. J. Chem. 1979, 32, 2257.

[8] P.E. Goss, C.L. Reid, D. Bailey, J.W. Dennis, Clin. Cancer Res. 1997, 3, 1077.

[9] T. Kino, N. Inamura, H. Nakahara, K. Kiyoto, T. Goto, H. Terano, M. Kohsaka, H. Aoki, H. Imanaka, J. Antibiot. 1985, 38, 936.
[10] W.H. Pearson, L. Guo, Tetrahedron Lett. 2001, 42, 8267.

[11] J.W. Dennis, S.L. White, A.M. Freer, D. Dime, Biochem. Pharmacol. 1993, 46, 1459.

[12] W.H. Pearson, E.J. Hembre, Tetrahedron Lett. 2001, 42, 8273.

[13] S. Gerber-Lemaire, F. Popowycz, E. Rodriguez-García, A.T. Carmona-Asenjo, I. Robina, P. Vogel, ChemBioChem 2002, 3 , 466.

[14] F. Popowycz, S. Gerber-Lemaire, E. Rodriguez-García, C. Schütz, P. Vogel, Helv. Chim. Acta 2003, 86, 1914.

[15] A.T. Carmona-Asenjo, F. Popowycz, S. Gerber-Lemaire, E. Rodriguez-García, I. Robina, P. Vogel, Bioorg. Med. Chem. 2003, 11, 4897.

[16] F. Popowycz, S. Gerber-Lemaire, C. Schütz, P. Vogel, Helv. Chim. Acta 2004, 87, 800 .
[17] G.W.J. Fleet, J.C. Son, Tetrahedron 1988, 9, 2637.

[18] N. Ikota, H. Nakagawa, S. Ohno, K. Noguchi, K. Okuyama, Tetrahedron 1998, 54, 8985.

[19] S. Howard, C. Braun, J. McCarter, K.W. Moremen, Y.F. Liao, S.G. Withers, Biochem. Biophys. Res. Commun. 1997, 238, 896.

[20] H. Fiaux, F. Popowycz, S. Favre, C. Schütz, P. Vogel, S. Gerber-Lemaire, L. Juillerat-Jeanneret, J. Med. Chem. 2005, 48, 4237.

[21] Y. Berger, A. Greppi, O. Siri, R. Neier, L. Juillerat-Jeanneret, J. Med. Chem. 2000, $43,4738$. 